\title{
Optimal control of a batch bioreactor for the production of a novel antifungal substance CF66I
}

\author{
Chun-Shan Quan ${ }^{1,2^{\star}}$, Xin Li $^{3,4}$, Jun-Hua Wang ${ }^{1,2}$, Wei Zheng ${ }^{1,2}$ and Sheng-Di Fan ${ }^{1,2}$ \\ ${ }^{1}$ Life Science College, Dalian Nationalities University, Economical and Technological Development Zone, Dalian, 116600, \\ China. \\ ${ }^{2}$ Key Laboratory of Biotechnology and Bio-Resources Utilization, State Ethnic Affairs Commission and Ministry of Educ \\ ation, Dalian Nationalities University, Dalian 116600, China. \\ ${ }^{3}$ Dalian Institute of Chemical Physics, Chinese Academy of Sciences, 457 Zhong-shan Road, Dalian, 116023, China. \\ ${ }^{4}$ Graduate University of the Chinese Academy of Sciences, Beijing, 100049, China.
}

Accepted 21 July, 2009

\begin{abstract}
More than $\mathbf{8 0} \%$ of the plant diseases are caused by fungi. Usually, fungi not only destroy the plants, but also produce mycotoxins that are harmful to human health. At present, chemical fungicides are mainly used for the prevention of fungi-related plant diseases, however, research and development of biological prevention and controlling are of great importance. In this work, the effects of $\mathrm{pH}$ and temperature on cell growth and CF66I formation in batch culture of Burkholderia cepecia CF-66 were studied. The $\mathrm{pH}$ value has a marked effect on cell growth and production of CF66I. The lag phase was much longer when pH set lower (e.g.5.0) or higher (e.g.8.0). For earlier phase, optimal pH value was 6.0, because the lag phase can be shortened and the whole fermentation phase can also be shorten and then quickly goes into CF66I production phase. In the late phase, the higher $\mathrm{pH}$ is in favor of the production of CF66I. Different temperature have different effect on cell yield, specific growth rate, CF66I yield and specific synthesis rate. In the prophase of fermentation, it is better to set higher temperature to make the cell growth maximizing as soon as possible. However in mid-anaphase, lower temperature shortens the fermentation time, reduce heating energy and the cost. According about results, an optimal control strategy was constructed.
\end{abstract}

Key words: Burkholderia cepacia, antifungal activity, optimal control, CF66I.

\section{INTRODUCTION}

Every year, plant-pathogenic fungi such as Fusarium sp., Pythium sp. and Rhizoctonia solani cause millions of dollars worthy of crop damage all over the world despite the extensive use of chemical pesticides. Meanwhile, concerns about food safety, environmental quality and pesticide resistance have dictated the need for more useful techniques (Copping and Menn, 2000). One of most promising alternatives in the context of agricultural world is the use of bioproducts from microorganisms, playing an important role in agriculture sustainable models. Recently, many reports have been published concerning to new antibiotics having biocontrol activity

\footnotetext{
*Corresponding author. E-mail: mikyeken@dlnu.edu.cn. Tel.: $+86-411-8753-2756$ or $\quad+86-(0) 411-87656005$. Fax: $+86-411-87644496$.
}

including some kinds of bacteriocins, alkaloids, lipopeptides and polypeptide (Arima et al., 1968; Cupples and Sen, 1978; Wakayama et al., 1984; El-Banna and Winkelmann, 1998). Some antibiotics, such as polyoxin, validamycin, amipurimycin and abomycin, have been extensively used in agricultural biocontrol (Cabib et al., 1991; Yu et al., 2005). However, there are many problems due to the limited antifungal spectrum, long time to become effective against the pathogenic fungi and their instability. Most of all, the inhibitory efficacy against soilborne plant pathogens is associated with the productivity of antibiotics, however, in general the productivity is low because they are secondary metabolites.

The bacterium Burkholderia cepacia is a plant growth promoting rhizobacteria. Early in 1990s, it has already been used as a biocontrol compound for protecting crops from fungal disease and certain isolates of the $B$. cepacia complex are commercially available for control of plant 
pathogenic fungi and nematodes (Deny ${ }^{\mathrm{TM}}$, Stine Microbial Products, USA). Different $B$. cepacia strains have been reported to be an effective biocontrol compound for Pythium-induced damping off and Aphanomyces-induced root rot of pea (Parke et al., 1991; King and Parke, 1993; Bowers and Parke, 1993), Botrytis-induced gray mold of apple (Janisiewiez and Roitman, 1988), Rhizoctonia solani induced root rot of Poinsettia (Cartwright and Benson, 1994), and other fungal diseases (Fridlender et al., 1993), because it can produce many secondary compounds such as pyrrolnitrin, altericidins, cepacin and other unidentified volatile or nonvolatile compounds which showed strong antifungal activity (Kirinuki et al., 1977; Hwang et al., 2002; Parker et al., 1984).

Recently, a strain identified as $B$. cepacia CF-66 with strong antifungal activity has been isolated from the compost samples, which strongly inhibits the growth of many plant pathogens such as $R$. solani. A novel antifungal compound CF66I was also isolated from the culture of $B$. cepecia CF-66 strain and preliminary spectra data suggested it was most probably a polyether antibiotic with aliphatic chains (Quan et al., 2005; Quan et al., 2006). The effect of medium components on CF66I production was investigated by shaking-flask culture through statistics-based experimental design, previously. A fractional factorial design augmented with center points revealed that sodium citrate and yeast extract were the most significant factors, which influenced CF66I production positively, while the other factors were not important with the levels tested.

The method of steepest ascent was also used to approach the proximity of optimization. The optimized medium allowed the activity of CF66I to be increased from $2.12 \mathrm{U} / \mathrm{ml}$ to $6.24 \mathrm{U} / \mathrm{ml}$, about $200 \%$ higher than the original medium (Zeng et al., 2007). Effects of oxygen transfer coefficient $\left(\mathrm{K}_{\mathrm{La}}\right)$ and dissolved oxygen concentration (DO) on batch fermentation of CF66l were investigated with 3.7-L jar fermentor in the previously study. It was found that high $\mathrm{K}_{\mathrm{La}}$ level was disadvantageous to the cell growth and the CF66I production at the beginning of the fermentation. The $\mathrm{K}_{\mathrm{La}}$ value was optimized at 121.2 $\mathrm{h}^{-1}$ and the DO concentration was optimized at $15 \%$ air saturation. Consequently, a two-stage oxygen supply control strategy was applied in which $\mathrm{K}_{\mathrm{La}}$ value was fixed at $121 \mathrm{~h}^{-1}$ at the first $28 \mathrm{~h}$, then the DO value was changed to $15 \%$ air saturation by varying the stirring speeds and the aeration rate until the end of the fermentation to increase the production of CF66l. By applying this strategy, the maximal antifungal activity of CF66I had an improvement and reached $7.360 \mathrm{U} / \mathrm{ml}$, which higher than those of constant operations.

Medium $\mathrm{pH}$ and culture temperature are key operating parameters of CF66I production process. The object of this work was to evaluate the effects of $\mathrm{pH}$ and temperature on cell growth and CF66I formation in batch fermentation of $B$. cepecia CF-66. An optimal pH and temperature control strategy, which maximize antifungal activity of CF66I and CF66I productivity for batch CF66I fermentation was demonstrated.

\section{MATERIALS AND METHODS}

\section{Chemicals}

Reagents for cultivation such as yeast extract, beef extract, peptone and agar were purchased from Wako, Japan. D-Glucose, Mg $\mathrm{Cl}_{2} \cdot 6 \mathrm{H}_{2} \mathrm{O}, \mathrm{NH}_{4} \mathrm{Cl}, \mathrm{Fe}_{2} \mathrm{SO}_{4} \cdot 7 \mathrm{H}_{2} \mathrm{O},\left(\mathrm{NH}_{4}\right)_{2} \mathrm{SO}_{4}, \mathrm{~K}_{2} \mathrm{HPO}_{4}$ and $\mathrm{KH}_{2} \mathrm{OP}_{4}$, were obtained from Shenlian Chemical, China. All other reagents used were of the highest grade available unless otherwise indicated.

\section{Microorganism and culture maintenance}

B. cepacia CF-66 isolated from compost was used throughout this study. The strain was cultivated on PDA (potato-dextrose-agar) slants and incubated at $30^{\circ} \mathrm{C}$ for $12 \mathrm{~h}$, then stored at $4^{\circ} \mathrm{C}$. Pichia membranaefaciens was used as indicator microorganism. This yeast was grown on a medium of glucose $30 \mathrm{~g} / \mathrm{L}$, yeast extract $4 \mathrm{~g} / \mathrm{L}$ and peptone $5 \mathrm{~g} / \mathrm{L}$, at $28^{\circ} \mathrm{C}$ for $12 \mathrm{~h}$ on a reciprocal shaker at 200 rpm.

\section{Cultivation media}

Medium $\mathrm{S}$ composed of yeast extract $8 \mathrm{~g} / \mathrm{L}$, Na-Citrate $7.5 \mathrm{~g} / \mathrm{L}$, $\mathrm{NH}_{4} \mathrm{Cl} 2.0 \mathrm{~g} / \mathrm{L}, \mathrm{MgSO}_{4} \cdot 7 \mathrm{H}_{2} \mathrm{O} 0.5 \mathrm{~g} / \mathrm{L}, \mathrm{K}_{2} \mathrm{HPO}_{4} 1.5 \mathrm{~g} / \mathrm{L}, \mathrm{KH}_{2} \mathrm{PO}_{4} 0.6$ $\mathrm{g} / \mathrm{L}$ was used seed cultivation. Medium $\mathrm{F}$ was an optimal medium developed by Medium $S$ in shake flask culture for enhanced production of CF66I by B. cepacia CF-66 (Zeng et al., 2007), which composed of yeast extract $19.61 \mathrm{~g} / \mathrm{L}, \mathrm{Na}$-Citrate $34.48 \mathrm{~g} / \mathrm{L}, \mathrm{NH}_{4} \mathrm{Cl}$ $2.0 \mathrm{~g} / \mathrm{L}, \mathrm{MgSO}_{4} \cdot 7 \mathrm{H}_{2} \mathrm{O} 0.5 \mathrm{~g} / \mathrm{L}, \mathrm{K}_{2} \mathrm{HPO}_{4} 1.5 \mathrm{~g} / \mathrm{L}, \mathrm{KH}_{2} \mathrm{PO}_{4} 0.6 \mathrm{~g} / \mathrm{L}$.

\section{Culture methods}

A loop of cells grown on a PDA slant was inoculated into 1000 ml-flask containing $200 \mathrm{ml}$ medium S. After $12 \mathrm{~h}$ cultivation at $30^{\circ} \mathrm{C}$ and $200 \mathrm{rpm}$ on a rotary shaker, the seed was inoculated into a 3.7-L stirred tank bioreactor (KLF2000 3.7 L, BioEngineering, Switzerland), equipped with a pH probe (Type 465-35-90-K9; Mettler Toledo) and a dissolved oxygen probe. The aeration rate was $250 \mathrm{~L} / \mathrm{h}$ and the agitation speed was at 550-650 rpm. To control pH at a set level, $2 \mathrm{~N}$ $\mathrm{NaOH}$ and $2 \mathrm{~N} \mathrm{H}_{2} \mathrm{SO}_{4}$ was automatically added to the culture broth. Generally, foaming appeared in the culture medium after $12 \mathrm{~h}$ of cultivation, a situation leading to unstable culture conditions that can be avoided by addition of anti-foaming agent KM-70 (ShinEtsu Chemical Co. Ltd., Tokyo). The temperature was controlled according to the need of the experiments. During the fermentation, the $\mathrm{pH}$ and DO was monitored on line, and cell growth, residual carbon source and antifungal activity was analyzed off-line by the method described below. For each experiment, 13 samples were taken and analyzed for three times.

\section{Analytical methods}

For the measurement of the concentration of the cells, biomass concentration was estimated from optical density using a predetermined correlation between absorbance at $660 \mathrm{~nm}$ and dry mass weight (DCW). The amount of sodium citrate in the culture broth was determined using high performance liquid chromatography (HPLC) following by the method (Marsili et al., 1981). The HPLC system for analysis of sodium citrate was composed of a Hitachi L-6200 solvent delivery controller, a Hitachi 4200 H UV-vis detector, a Hitachi-D-2500 Chromato-Integrator and 
a Aminex® HPX-87H (BIO-RAD, U.S.A.) column. The injection volume was $20 \mu \mathrm{l}$. The sample was eluted with a mobile phase comprising $0.05 \mathrm{M} \mathrm{H}_{2} \mathrm{SO}_{4}$ at a flow rate of $0.6 \mathrm{ml} / \mathrm{min}$. The chromatogram was monitored at $210 \mathrm{~nm}$.

The antimicrobial activity of CF66I in the culture broth was measured by Hultmark method (Lee et al., 2004) with slight modification. The culture broth was centrifuged for $10 \mathrm{~min}$ at $15,000 \mathrm{rpm}$ and then their supernatant was filtrated through a $0.22-\mu \mathrm{m}$ filter. The indicator microorganism cultivated into log growth phage was diluted with liquid medium, in which absorbance at $554 \mathrm{~nm}$ was 0.2 . Fivehundred microlitre of above culture broth sterilized with micro-filter was added into $2 \mathrm{ml}$ of indicator diluents, cultivated for $2 \mathrm{~h}$ at $30^{\circ} \mathrm{C}$, and then cooled in ice bath for 20 min before determine the change of absorbance at $554 \mathrm{~nm}$. For the control, $500 \mu \mathrm{l}$ of medium F was added. Antimicrobial activity was calculated as follow $U=$ $\left(\Delta \mathrm{A}_{0}-\Delta \mathrm{A}_{\mathrm{s}}\right) / \Delta \mathrm{A}_{0} \times \mathrm{N}$, in this formula $\Delta \mathrm{A}_{0}$ and $\Delta \mathrm{A}_{\mathrm{s}}$ are absorbencies of control and sample culture broth and $\mathrm{N}$ is dilution multiple.

\section{RESULTS}

\section{Effects of $\mathrm{pH}$ on cell growth and CF66I production}

Time-course data on cell, CF66I production and sodium citrate concentration of one batch culture with initial $\mathrm{pH}$ 6.0 and four $\mathrm{pH}$ controlled batch cultures with $\mathrm{pH}$ set point ranging 5.0 to 8.0 are shown in Figures 1 and 2. While culture $\mathrm{pH}$ was uncontrolled it increased gradually from 6.0 to 8.5 at $16 \mathrm{~h}$ of fermentation and kept higher than 8.0 until the end of fermentation. As the results, the cells reached stationary phase at $12 \mathrm{~h}$ of fermentation with a maximum concentration of $2.04 \mathrm{~g} / \mathrm{L}$ and quickly turned into death phage. However, the production of CF66I was beginning at $12 \mathrm{~h}$ and increased to $2.37 \mathrm{U} / \mathrm{ml}$ at $52 \mathrm{~h}$.

The effects of $\mathrm{pH}$ values at the range of 5.0 to 8.0 on CF66I production were studied. Time courses of CF66I fermentation at the different $\mathrm{pH}$ are shown in Figure 2. At $\mathrm{pH}$ lower than 5.0 and $\mathrm{pH}$ higher than 8.0, little cell growth occurred, so their time courses of CF66l fermentation were not listed in Figure 2. At pH $5.0 \mathrm{DCW}$ and CF66I activity reached maxima of $2.582 \mathrm{~g} / \mathrm{L}$ and $1.553 \mathrm{U} / \mathrm{ml}$ at 46 and $36 \mathrm{~h}$, respectively. However, the lag time of cell growth was very long, almost lasting $12 \mathrm{~h}$. Moreover, the cells grew slowly during the whole CF66I fermentation, so it indicated that $\mathrm{pH} 5.0$ was not appropriate for CF66I production. Time course of CF66I production at $\mathrm{pH} 6.0$

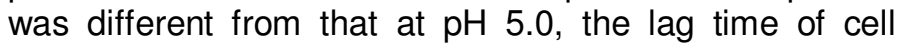
growth was the shortest than all tested $\mathrm{pH}$ value, DCW reached the maximum value of $3.999 \mathrm{~g} / \mathrm{L}$ at $32 \mathrm{~h}$, while the maximum activity of CF66I was obtained at $48 \mathrm{~h}$. At $\mathrm{pH} 7.0$ and $\mathrm{pH} 8.0$, the lag time was longer than that of $\mathrm{pH}$ 6.0 , the maximum of DCW was $4.615 \mathrm{~g} / \mathrm{L}$ at 12 and $24 \mathrm{~h}$, respectively. Time course of CF66I production at $\mathrm{pH} 7.0$ and 8.0 were similar, the difference was that the maximum activity $(8.166 \mathrm{U} / \mathrm{ml})$ of $\mathrm{CF} 66 \mathrm{l}$ at $\mathrm{pH} 8.0$ is higher than that at $\mathrm{pH} 7.0(6.996 \mathrm{U} / \mathrm{ml})$.

According to the above results, it is clear that $\mathrm{pH}$ plays an important role in the process of CF66I fermentation. At $\mathrm{pH}$ lower than 5.0 and higher than 8.0, the lag time of cell growth was longer, CF66I formation rate was enhanced by increasing of $\mathrm{pH}$ value.
The specific growth rate was determined from the slope of the semi-logarithmic plot of cell density versus fermentation time, $\mu=\frac{1}{x} \frac{d x}{d t}=\frac{1}{x} \lim _{\Delta t \rightarrow 0} \frac{\Delta x}{\Delta t} \cdot \mu_{\text {cell }}$ at definite time was obtained through computing cell density by interpolating calculating of experimental data with Origin 7.0 and Microsoft Excel. Time courses of the specific cell growth rate at different $\mathrm{pH}$ are shown in Figure 3. As shown in Figure 3 , profiles of $\mu_{\text {cell }}$ at different $\mathrm{pH}$ had similar tendencies, $\mu_{\text {cell }}$ was the highest at $\mathrm{pH} 7.0$ before $12 \mathrm{~h}$, but the highest at $\mathrm{pH} 8.0$ after $12 \mathrm{~h}$. The $\mu_{\max }$ at different $\mathrm{pH}$ showed that the optimum $\mathrm{pH}$ for cell growth was 6.0 and $\mu_{\max }$ reached to $0.759 \mathrm{~h}^{-1}$. It is indicated that, at early phase of CF66I fermentation (before $12 \mathrm{~h}$ ), $\mathrm{pH}$ should be controlled at 6.0 in order to shorten the lag phase of cell growth and thus total fermentation time and to move up the time of CF66I formation.

The specific CF66I formation rate $\left(q_{p}\right)$ was determined from reciprocal of cell density and the slope of CF66I activity versus fermentation time, $\mathrm{q}_{\mathrm{p}}=\frac{1}{x} \frac{d p}{d t}=\frac{1}{x} \lim _{\Delta t \rightarrow 0} \frac{\Delta p}{\Delta t}$ $\mathrm{q}_{\mathrm{p}}=\frac{1}{x} \frac{d p}{d t}=\frac{1}{x} \lim _{\Delta t \rightarrow 0} \frac{\Delta p}{\Delta t} \cdot \mathrm{q}_{\mathrm{p}}$ was obtained with the method similar to $\mu_{\text {cell }}$. The duration of reaching maximum $\mathrm{q}_{\mathrm{p}}$ was $32 \mathrm{~h}$, and same at different $\mathrm{pH}$. Although the highest $\mathrm{q}_{\mathrm{p}}$ could be achieved at $\mathrm{pH} 8.0$, fastest increasing rate was observed at $\mathrm{pH} 6.0$. At $\mathrm{pH} 5.0$, the $\mathrm{CF} 66 \mathrm{I}$ formation rate was significantly low compared to that at other tested $\mathrm{pH}$ value and duration of CF66I formation was very short. Therefore, at early phase of CF66I fermentation, it is appropriate to control $\mathrm{pH}$ at low value (e.g. $\mathrm{pH}$ 6.0) to maximize $\mathrm{q}_{\mathrm{p}}$, while at mid- and later-fermentation phase, higher $\mathrm{pH}$ (e.g. $\mathrm{pH}$ 8.0) was more proper in order to maintain high $\mathrm{q}_{\mathrm{p}}$.

\section{pH control strategy of batch CF66I production by $B$. cepacia CF-66}

From the results discussed above, relative lower $\mathrm{pH}$ at earlier fermentation stage not only made the lag phase of cell growth shorter but also was advantageous to cell growth and CF66I formation. At later fermentation stage, properly increasing $\mathrm{pH}$ value can strengthen cell growth and CF66I formation, thus, increase CF66I fermentation level. During the whole process, the suitable $\mathrm{pH}$ for cell growth and CF66I formation are different, it is favorable to use a three-stage $\mathrm{pH}$ control process instead of constant $\mathrm{pH}$ process. As suggested from the results shown in Figures 2 and 3 , an optimal $\mathrm{pH}$-shift strategy was developed as following: $\mathrm{pH}$ was controlled at 6.0 during $0-12 \mathrm{~h}$ and then raised naturally to $\mathrm{pH} 8.0$ without control for the second $12 \mathrm{~h}$, maintained the $\mathrm{pH}$ value at 8.0 till the end of the fermentation.

Time course of $\mathrm{pH}$-shift strategy is shown Figure 4. When $\mathrm{pH}$ was controlled at 6.0 at the early phage, the lag 


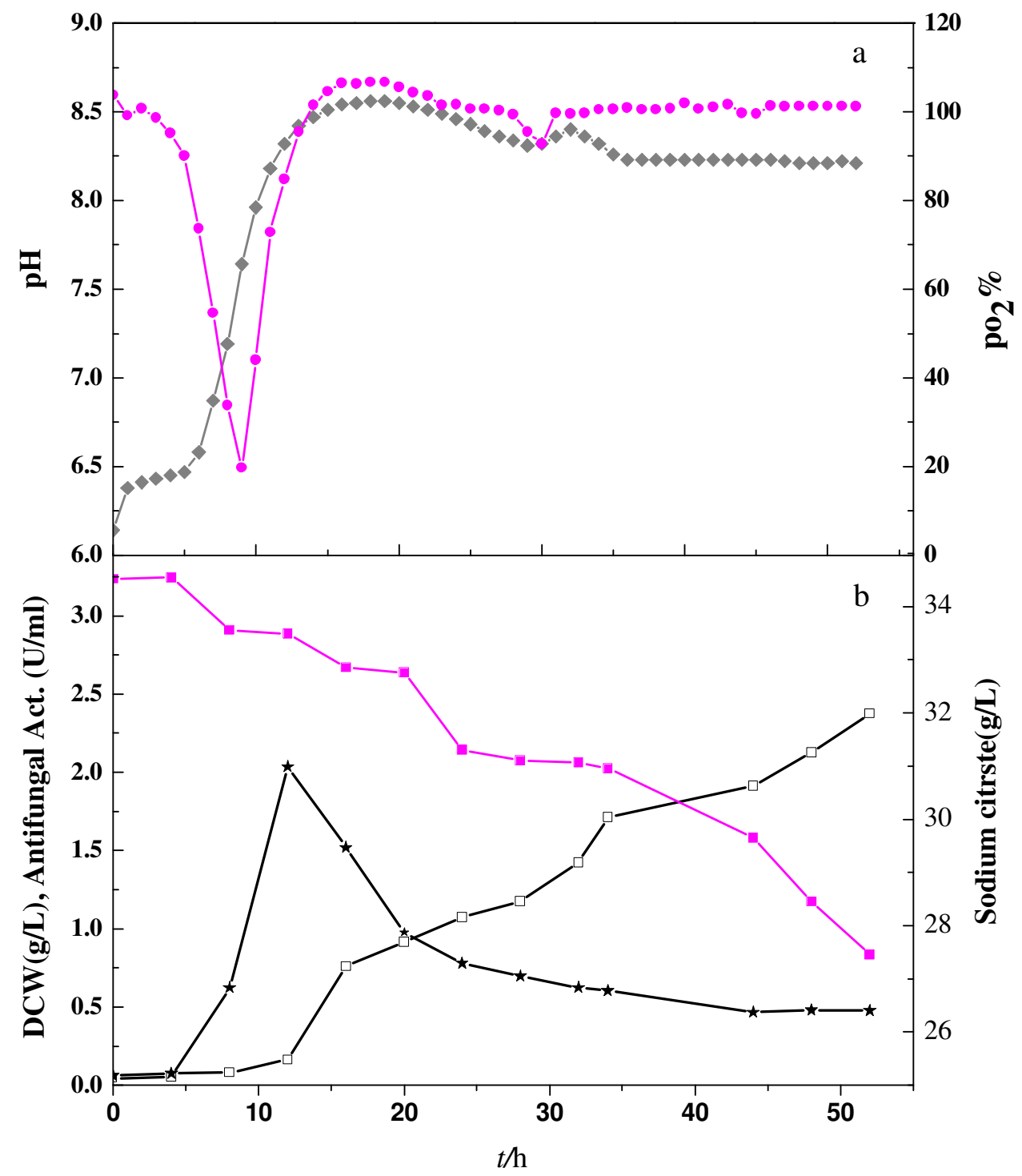

Figure 1. Time profile of the batch cultivation at natural $\mathrm{pH}$ value. (a) $\mathrm{pH}$ and $\mathrm{PO}_{2} \%$; (b) cell growth, antifungal activity and substrate consume. Symbols: - - $\mathrm{pH} ;-\bullet-\mathrm{PO}_{2} \%$; - - - sodium citrate; - - antifungal activity; - - cell growth.

time was short, cell growth rate was high than that of at $\mathrm{pH}$ 8.0. After $\mathrm{pH}$ was shifted to 8.0 at $24 \mathrm{~h}$, cell growth rate continued keeping at high levels and CF66I production was on exponential phase. The CF66I production was kept maximum after $48 \mathrm{~h}$, CF66l activity was reached to $8.599 \mathrm{U} / \mathrm{ml}$. CF66I yield and CF66I productivity were increased by 15.4 and $5.3 \%$, respectively, compared with the best results of $\mathrm{pH}$ process. It is concluded that the proposed three-step $\mathrm{pH}$-shift strategy can obviously improve CF66I fermentation level.

\section{Effects of temperature on cell growth and CF66I production}

The effects of temperature on cell growth and CF66I production of $B$. cepacia Cf-66 is shown in Figure 5 . Maximum CF66l activity was obtained at $25^{\circ} \mathrm{C}$, but cell growth was more rapid at $30^{\circ} \mathrm{C}$ (Figure 5a). Temperature which is higher than $33^{\circ} \mathrm{C}$ or lowers than $25^{\circ} \mathrm{C}$ is not suitable for cell growth. When the temperature control to $33^{\circ} \mathrm{C}$, although lag phage was short, but cell growth very quickly achieve a stationary phage. At $25^{\circ} \mathrm{C}$, CF66I activity was increased rapidly than others temperatures and reached maximum at the end of fermentation though CF66I production appears late (Figure 5b).

As shown in Figure $5 \mathrm{c}$, along with the temperature increase, the consumption rate of sodium citrate and cell growth go fast evident and the time of entering into stationary phage is short significantly. Sodium citrate was nearly exhausted after $20 \mathrm{~h}$ at $33^{\circ} \mathrm{C}$ and the concentration 


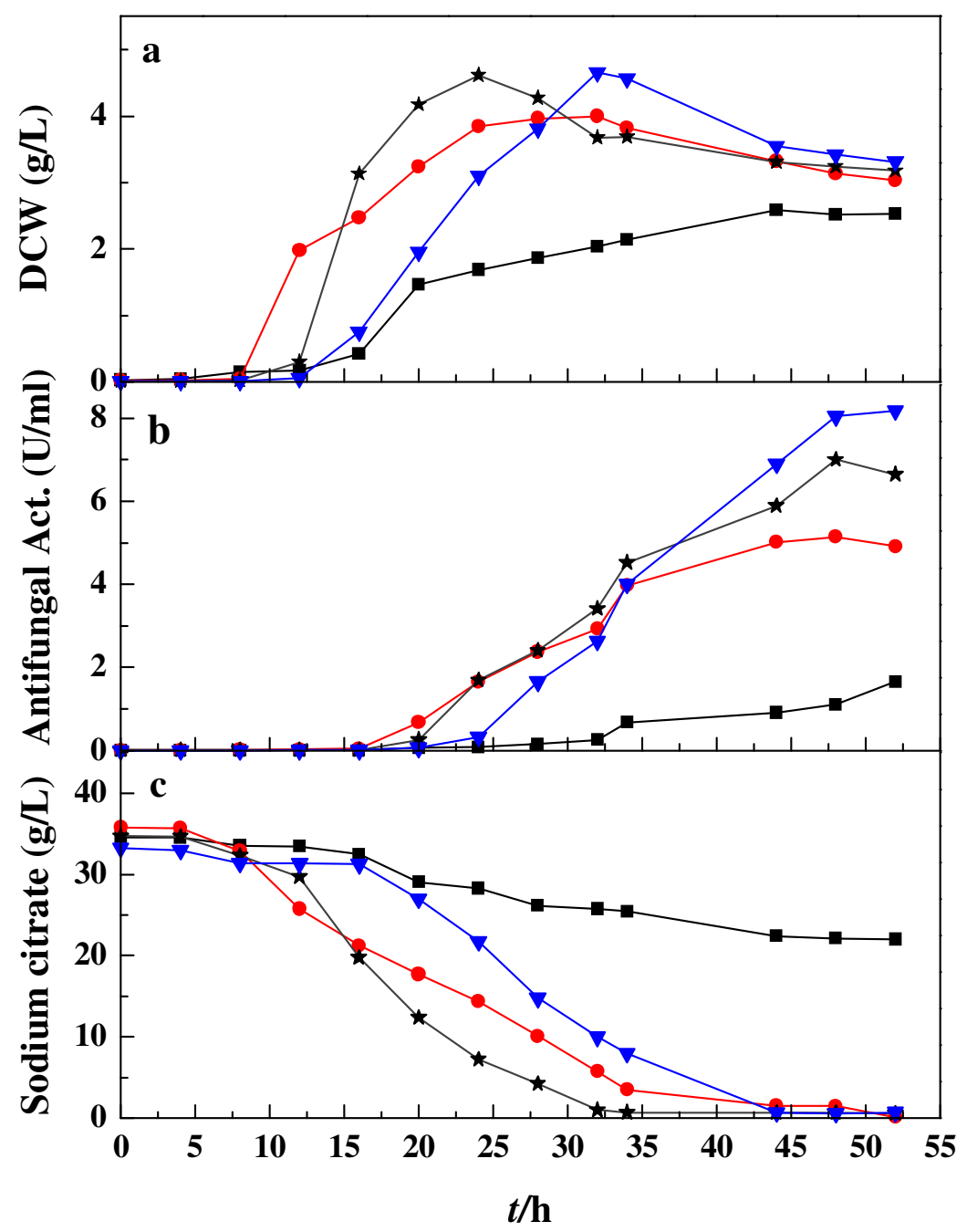

Figure 2. Effects of $\mathrm{pH}$ on biomass (a), antifungal activity (b), and substrate

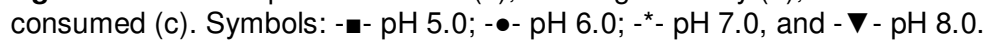

of residual substrate was $1.89 \mathrm{~g} / \mathrm{L}$. At $30^{\circ} \mathrm{C}$, sodium citrate was consumed mostly after $28 \mathrm{~h}$ and the concentration of substrate was $0.11 \mathrm{~g} / \mathrm{L}$. However, at $23^{\circ} \mathrm{C}$, the substrate remained high concentration of $19.96 \mathrm{~g} / \mathrm{L}$ until the end of fermentation process. Therefore, adopting higher

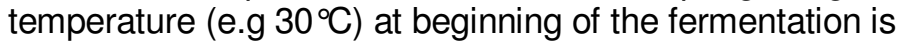
profit to shorten lag phase and fermentation time, it also can increase use ratio of substrate.

\section{Temperature control strategy of batch CF66I production by $B$. cepacia CF-66}

The optimum fermentation temperature generally mean that it not only suit for cell growth, but also profit for metabolite synthesis. However, in the production process, the optimum growth temperature is differing from the optimum production temperature. It is necessary that to unify promoting cell growth and increasing product synthesis with controlling optimum temperature in different phases. When control fermentation temperature was constant, higher temperature at prophase can not only shorten cell growth lag phase, decrease total fermentation time and profit cell growth, but also enhance efficiency of CF66I synthesis. In the later phase of fermentation, degrading fermentation temperature which only can maintain normal cell metabolism of $B$. cepacia CF-66 is effective to raise CF66l synthesis rate and improve the total fermentation level. Thus, following control strategy was used: control temperature at $30^{\circ} \mathrm{C}$ before $20 \mathrm{~h}$ and $25^{\circ} \mathrm{C}$ after $20 \mathrm{~h}$.

Figure 6 shows the fermentation course in $3.7 \mathrm{~L}$-jar fermentor using above two-stage temperature control strategy. It is indicated that cell growth lag phage was shorten, cell growth rate was faster and antifungal activity was reached to $11.349 \mathrm{U} / \mathrm{L}$ at $48 \mathrm{~h}$. Table 1 shows the comparison of key parameter under different temperature. CF66l's yield was raised obviously by two-stage tempe- 


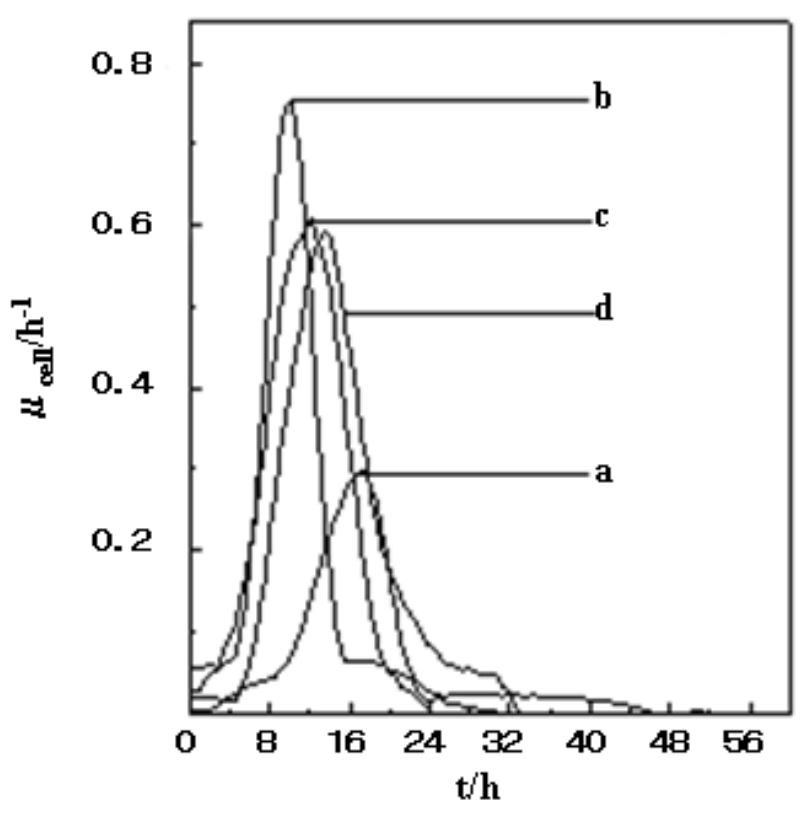

Figure 3. Time courses of specific CF66I formation rate under different pH; (a) 5.0 (b) 6.0 (c) 7.0 and (d) 8.0.

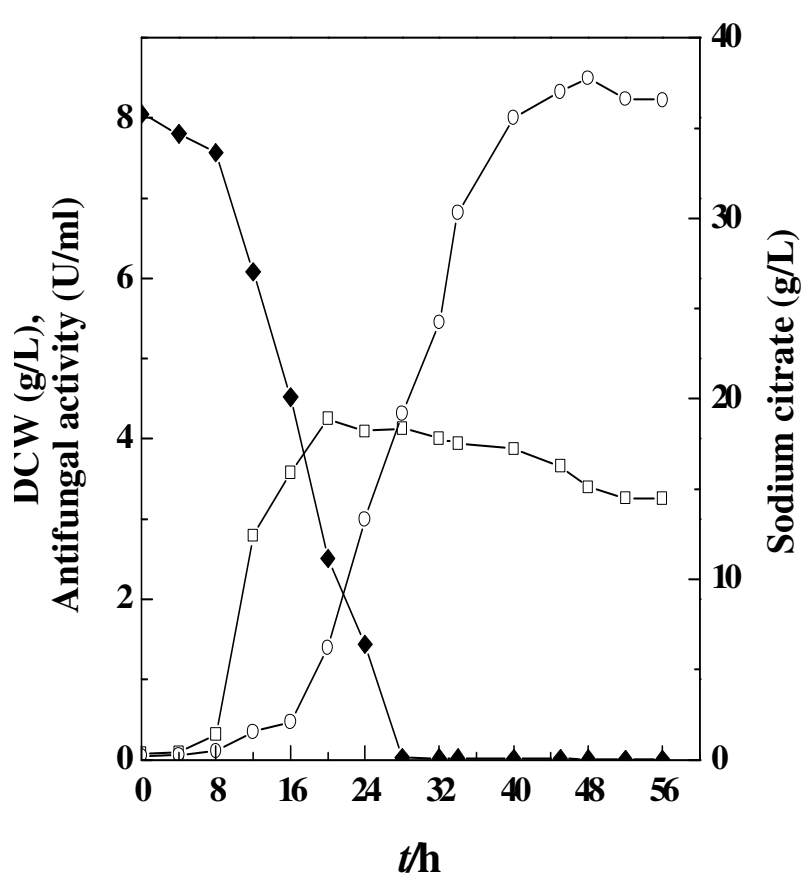

Figure 4. Time profile of CF66l production using a three-stage $\mathrm{pH}$ control strategy. Symbols: - sodium citrate; - - antifungal activity; and -๑- cell growth.

rature control strategy and the productivity was also enhanced markedly. The maximum antifungal activity was reached to $218.28 \mathrm{U} / \mathrm{L}$ which was enhanced to $26.1 \%$ than single temperature controlled and average specific CF66I production rate was $40.12 \mathrm{U} / \mathrm{L} / \mathrm{h}$.

\section{DISCUSSION}

B. cepacia consists of genotypically distinct but phenotypically similar groups of strains and closely related species, which have been collectively designated as the $B$. cepacia complex. Recent taxonomic analyses have demonstrated that the complex actually comprise a cluster of nine species and genomovars referred to as $B$. cepacia genomovar (I) B. multivorans (II) B. cenocepacia (III) B. stabilis (IV) B. vietnamiensis (V) B. dolosa (VI) B. ambifaria(VII) B. anthina (VIII) and B. pyrrocinia (IX) (Whitby et al., 2000; Payne et al., 2005; Ramette et al., 2005; Coenye et al., 2001a-c; Vandamme et al., 2002; Tabacchioni et al., 2002; LiPuma et al., 1999). Preliminary studies also indicated that most epidemic $B$. cepacia species isolated are genomovar II and III and that this species is associated with great morbidity and mortality than other members of the B. cepacia complex (LiPuma et al., 1999; Tabacchioni et al., 2002). B. cepacia genomovar V and VII have higher plant growth promoting activity and lower frequency recovery from cystic fibrosis than other members. The strain CF-66 with strong antifungal activity, which was isolated from compost, was identified as $B$. cepacia complex by morphological and biochemical tests and 16S rDNA sequence and species-specific PCR showed that this strain may belong to $B$. cepacia genomovar $\mathrm{V}, \mathrm{VI}$, or IX and the highest probability is $B$. cepacia genomovar $\mathrm{V}$. To avoid the risks caused by using $B$. Cepacia in biological control process, it is better to use the antimicrobial compounds extracted from the fermentation broth of $B$. Cepacia. This paper investigated the effect of $\mathrm{pH}$ value and temperature on fermentation process and the characteristics of fermentation kinetic by batch fermentation experiment with 3.7-L fermentor. The control parameters got from the experiment can be used for broad scale industrialization.

The $\mathrm{pH}$ of the culture medium is a very important parameter in the process of batch fermentation. It is the comprehend indicator of cell metabolic activity in certain environmental conditions. Not only the substrate, but also the protein molecule's ionization state changes with $\mathrm{pH}$ value of the broth. Especially for the enzyme, its ionization state is fairly sensitive to $\mathrm{pH}$ value. The growth and output production of the microorganism need many kinds of enzyme catalytic reactions, so $\mathrm{pH}$ value is the most important environmental factor of cell growth. The $\mathrm{pH}$ value will change with the accumulation of organic acids and amino acids, because the bacteria utilize the carbon and nitrogen source in the culture medium in a certain temperature and venting condition. The cell density of strain CF-66 maximize at $12 \mathrm{~h}$ and then will go to decline phase with no marked lag or stationary phase, if the $\mathrm{pH}$ value is unregulated. On the other hand, the plot of $\mathrm{pH}$ value suggests that $\mathrm{pH}$ have a fast upgrade (from 6.4 to 8.5) as the cells go into log phase and the biomass achieved maximum and then declined and autolyzed with no marked change of $\mathrm{pH}$ value. The $\mathrm{pH}$ value has a marked effect on cell growth and production of CF66I. The 

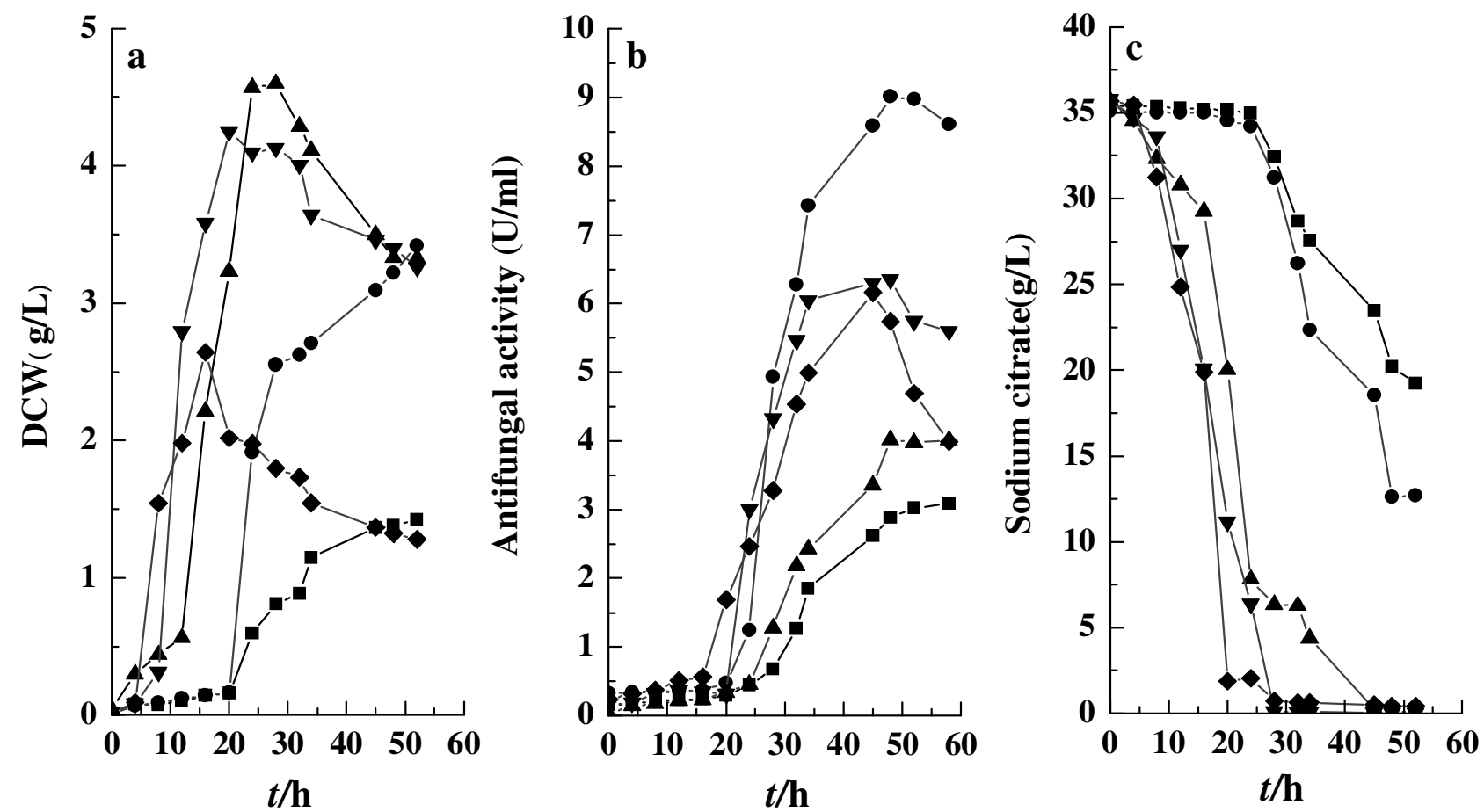

Figure 5. Effects of temperature on biomass (a), antifungal activity (b), and Substrate consumed (c). Symbols: $-\downarrow-33^{\circ} \mathrm{C}$; $-\mathbf{\nabla}$ $30^{\circ} \mathrm{C}$; - $\Delta$ - 28응 - $\bullet-25^{\circ} \mathrm{C}$; and $-\square-23^{\circ} \mathrm{C}$.

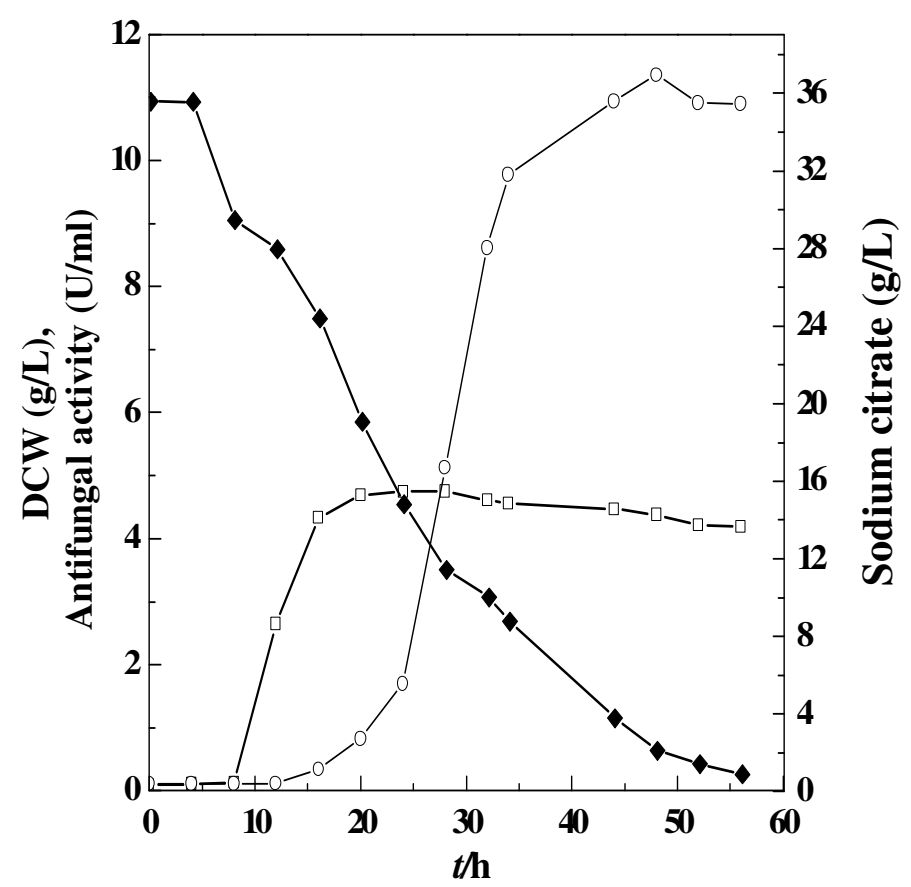

Figure 6. Effects of optimized $\mathrm{pH}$ control strategy on antifungal activity (-०-), cell growth (-๑-) and substrate consumed (- $\bullet$ ).

lag phase will be much longer when pH set lower (e.g. 5.0) or higher (e.g. 8.0). In the fermentation process, the higher $\mathrm{pH}$ during the late phase will be in favor of the production of CF66l. But for earlier phase $\mathrm{pH} 6.0$ will be better, because the lag phase can be shortened and the whole fermentation phase will be shorter and then quickly goes into CF66I production phase. According to the effects of $\mathrm{pH}$ on cell growth and CF66I production, $\mathrm{pH}$ value of fermentation broth go up to 8.0 spontaneously with the metabolic activity of the cells from 12 to $24 \mathrm{~h}$, therefore, the $\mathrm{pH}$ value is not necessary to control before $24 \mathrm{~h}$. Then sulfuric acid was need to be added to hold the $\mathrm{pH}$ value and prolong the stationary phase to prevent cell autolysis which often happened when $\mathrm{pH}$ higher then 8.0.

The growth of microorganism and the synthesis of the products need a series of enzyme catalysis reaction and temperature is the important terms. For enzyme kinetics, the rate of reaction, metabolism will step up and production phase will be ahead of schedule if set up the temperature higher. However, higher temperature can weaken the activity of the enzyme and the weaken rate corresponds to the temperature. It is reflected by aging of the cells, short of fermentation cycle and decrease of the production. For the above, it is essential to keep the temperature stable and suitable. In general, the best suitable temperature of cell growth and product synthesis are different and different stages need different temperature. Beside of the rate of reaction, the temperature can also affect the product synthesis by the physical property change of the broth. For example, the temperature can affect the rate of dissolve and delivery of oxygen in the substrate and the rate of disassociation and 
Table 1. Comparison of key parameters under different temperatures.

\begin{tabular}{|l|c|c|c|c|c|c|}
\hline \multirow{2}{*}{ Parameter } & \multicolumn{7}{|c|}{$\mathbf{T}\left({ }^{\circ} \mathbf{C}\right)$} \\
\cline { 2 - 7 } & $\mathbf{2 3}$ & $\mathbf{2 5}$ & $\mathbf{2 8}$ & $\mathbf{3 0}$ & $\mathbf{3 3}$ & $\mathbf{3 0 - 2 5}$ \\
\hline CF66I productivity $\left(\mathrm{U} \mathrm{L}^{-1} \mathrm{~h}^{-1}\right)$ & 58.05 & 173.13 & 77.22 & 122.04 & 118.32 & 208.48 \\
Average $\mu_{\text {cell }}\left(\mathrm{h}^{-1}\right)$ & 0.056 & 0.074 & 0.047 & 0.073 & 0.052 & 0.050 \\
Average $\mathrm{q}_{\mathrm{p}}\left(\mathrm{U} \mathrm{g}^{-1} \mathrm{~h}^{-1}\right)$ & 82.80 & 110.40 & 28.14 & 44.40 & 54.90 & 121.56 \\
Average $\mathrm{Y}_{\text {cell }}\left(\mathrm{g} \mathrm{g}^{-1}\right)$ & 0.087 & 0.152 & 0.155 & 0.172 & 0.167 & 0.153 \\
Average $\mathrm{Y}_{\text {CF66I }}\left(\mathrm{U} \mathrm{g}^{-1}\right)$ & 186.63 & 340.11 & 114.72 & 177.54 & 174.57 & 360.93 \\
\hline
\end{tabular}

*Using two-stage temperature control strategy.

absorption of the substrate. Beside of, the temperature can also affect the biosynthetic directions.

This paper has investigated the contribution of different temperature made to cell growth and CF66I synthesis. The result indicated that lower temperature (below $25^{\circ} \mathrm{C}$ ) can induce a longer lag phase and higher (up $30^{\circ} \mathrm{C}$ ) can make a shorter lag phase and the shorter time needed by DCW going up to maximum and the peak activity of product. Different temperature made different effect on cell yield, specific growth rate, CF66I yield, and specific synthesis rate. In the prophase of fermentation, it is better to set higher temperature (such as $30^{\circ} \mathrm{C}$ ) to make the cell growth maximizing as soon as possible. However in mid-anaphase, lower temperature is set to shorten the fermentation time, reduce heating energy and the cost. The final temperature controlling strategy of this paper is : $0 \sim 12 \mathrm{~h}, \mathrm{pH} 6.0,30^{\circ} \mathrm{C} ; 12 \sim 20 \mathrm{~h}, \mathrm{pH}$ to rise naturally, $30^{\circ} \mathrm{C}$;

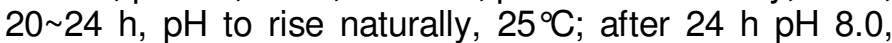
$25^{\circ} \mathrm{C}$, until the end. By this control strategy production strength was increased to $72.76 \mathrm{U} / \mathrm{L} / \mathrm{h}$, the maximum activity was raised to $26.1 \%$ than single temperature control and the average of CF66I synthetic rate reached $40.12 \mathrm{U} / \mathrm{g} / \mathrm{h}$.

\section{REFERENCES}

Arima K, Kakinuma A, Tamura G (1968). Surfactin, a crystalline peptidelipid surfactant produced by Bacillus subtilis: Isolation, characterization and its inhibition of fibrin clot formation. Biochem. Biophys. Res. Commun. 31: 488-494.

Bowers JH, Parke JL (1993). Epidemiology of Pythium damping-off and Aphanomyces root rot of peas after seed treatment with bacterial agents for biological control. Phytopathology 83: 1466-1473.

Cabib E (1991). Differential inhibition of chitin synthetases 1 and 2 from Saccharomyces cerevisiae by polyoxin $D$ and nikkomycins. Antimicrobl. Agents Chemother. 35: 170-173.

Cartwright DK, Benson MD (1994). Pseudomonas cepacia strain 5.5B and method of controlling Rhizoctonia solani therewith. US patent (22 February 1994) 5: 288-633.

Coenye T, Mahenthiralingam E, Henry D, LiPuma JJ, Laevens S, Gillis M, Speert DP, Vandamme P (2001a). Burkholderia ambifaria sp. nov., a novel member of the Burkholderia cepacia complex including biocontrol and cystic fibrosis-related isolates. Int $\mathrm{J}$ Syst. Evol. Microbiol. 51: 1481-1490.

Coenye T, LiPuma JJ, Henry D, Hoste B, Vandemeulebroecke K, Gillis M, Speert DP, Vandamme P (2001b). Burkholderia cepacia genomovar $\mathrm{VI}$, a new member of the Burkholderia cepacia complex isolated from cystic fibrosis patients. Int. J. Syst. Evol. Microbiol. 51: 271-279.

Coenye T, Vandamme P, Govan JRW, LiPuma JJ (2001c). Taxonomy and identification of the Burkholderia cepacia complex. J. Clin. Microbiol. 39: 3427-3436.

Copping LG, Menn JJ (2000). Biopesticides: a review of their action, applications and efficacy. Pest Manag. Sci. 56: 651-767.

Cupples D, Sen J (1978). Isolation and characterization of a bacteriocin produced by Pseudomonas solanacearum. J. Gen. Microbiol. 109: 293-303.

El-Banna N, Winkelmann G (1998). Pyrrolnitrin from Burkholderia cepacia: antibiotic activity against fungi and novel activities against streptomycetes. J. Appl. Microbiol. 85: 69-78.

Fridlender M, Inbar J, Chet I (1993). Biological control of soilborne plant pathogens by a, b-1, 3 glucanase-producing Pseudomonas cepacia. Soil Biol. Biochem. 25: 1211-1221.

Hwang J, Chilton WS, Benson DM (2002). Pyrrolnitrin production by Burkholderia cepacia and biocontrol of Rhizoctonia stemrot of poinsettia. Biol. Control 25: 56-63.

Janisiewiez WJ, Roitman J (1988). Biological control of blue mold and gray mold on apple and pear with Pseudomonas cepacia. Phytopathology. 78: 1697-1700.

King EB, Parke JL (1993). Biocontrol of Aphanomyces root rot and Pythium damping-off by Pseudomonas cepacia AMMD on four pea cultivars. Plant Dis. 77: 1185-1188.

Kirinuki T, Iwanuma K, Suzuki N, Fukami H, Ueno T (1977). Altericidins, a complex of polypeptide antibiotics produced by Pseudomonas sp. and their effect for the control of black spot of pear caused by Alternaria Kikuchiana Tanaka. Sci. Rep. Fac. Agric. Kobe Univ. 12: 223-230.

Lee DG, Hahm KS, Shin SY (2004). Structure and fungicidal activity of a synthetic antimicrobial peptides, P18, and its truncated peptides. Biotechnol. Lett. 26(4): 337-341.

LiPuma JJ, Dulaney BJ, McMenamin JD, Whitby PW, Stull TL, Coenye T, Vandamme P (1999). Development of rRNA-based PCR assays for

identification of Burkholderia cepacia complex isolated recovered from cystic fibrosis patients. J. Clin. Microbiol. 37: 3167-3170.

Marsili RT, Ostapenko H, Simmons RE, Green DE (1981). High Performance Liquid Chromatographic Determination of Organic Acids in Dairy Products. J. Food Sci. 46: 52-57.

Parke JL, Rand R, Joy A, King EB (1991). Biological control of Pythium-damping off and Aphanomyces root rot of peas by application of Pseudomonas cepacia or Pseudomonas fluorescens to seed. Plant Dis. 75: 987-992.

Parker WL, Rathnum ML, Seiner V, Trejo WH, Principe PA, Sykes RB (1984). Cepacin A and Cepacin B, two new antibiotics produced by Pseudomonas cepacia. J. Antibiot. 37: 431-440.

Payne GW, Vandamme P, Morgan SH, LiPuma JJ, Coenye T, Weightman AJ, Jones TH, Mahenthiralingam E (2005). Development of a recA gene-based identification approach for the entire Burkholderia cepacia genus. Appl. Environ. Microbiol. 71: 3917-3927.

Quan CS, Zheng W, Cao ZM, Wang JH, Fan SD (2005). Purification and properties of anitibiotic from Burkholderia cepacia CF-66. Acta Microbiol. Sin. 45: 707-710.

Quan CS, Zheng W, Liu Q, Ohta Y, Fan SD (2006). Isolation and characterization of a novel Burkholderia cepacia with strong antifungal activity against Rhizoctonia solani. Appl. Microbiol. Biotech. 72: 1276-1284.

Ramette A, LiPuma JJ, Tiedje JM (2005). Species abundance and 
diversity of Burkholderia cepacia complex in the environment. Appl. Environ. Microbiol. 71: 1193-1201.

Tabacchioni S, Bevivino A, Dalmastri C, Chiarini L (2002). Burkholderia cepacia complex in the rhizosphere: a minireview. Ann. Microbiol. 52: 103-117.

Vandamme P, Henry D, Coenye T, Nzula S, Vancanneyt M, LiPuma JJ, Speert DP, Govan JRW, Mahenthiralingam E (2002). Burkholderia anthina sp. nov. and Burkholderia pyrrocinia, two additional Burkholderia cepacia complex bacteria, may confound results of new molecular diagnostic tools. FEMS Immunol. Med. Microbiol. 33: 143-149.

Wakayama S, Ishikawa F, Eishi K (1984). Mycocerein, a novel antifungal peptide antibiotic produced by Bacillus cereus. Antimicrobl. Agents Chemother. 26: 936-940.
Yu FY, Li ZH, Zeng HC (2005). Progress on the research in antifungal agricultural antibiotics. Chin. J. Tropical Agric. 25: 60-65.

Zeng YF, Quan CS, Liu Q, Fan SD (2007). Medium optimization for the novel antifungal material by Burkholderia cepacia CF-66. China Biotechnol. 26(9): 56-60.

Whitby PW, Carter KB, Hatter KL, LiPuma JJ, Stull TL (2000). Identification of members of the Burkholderia cepacia complex by species-specific PCR. J. Clin. Microbiol. 38: 2962-2965. 